\title{
ANALISIS PENAWARAN EKSPOR TEKSTIL DAN PRODUK TEKSTIL INDONESIA KE ASEAN (Studi Kasus Negara Malaysia, Thailand, Vietnam, Philipina dan Kamboja)
}

\author{
Faiq Fuadi ${ }^{1}$ \\ Departemen IESP Fakultas Ekonomika dan Bisnis Universitas Diponegoro \\ Jl. Prof. Soedharto, SH. Tembalang, Semarang 50239, Phone: +622476486851
}

\begin{abstract}
International trade plays an important role in economic growth after consumption, investment and government spending. the industrial sector is encouraged to increase international trade, especially non-oil exports. Textiles and textile products (TPT) is one of the most important parts of Indonesian non-oil industry, this is because the textile industry contributes substantially to GDP. This study aimed to analyze the effect of the exchange rate, international prices of textile and textile domestic price index to the volume of Indonesian textile export supply in some ASEAN countries (Malaysia, Thailand, Vietnam, the Philippines and Cambodia).

The data used in this research are secondary data in the period January 2011 to December 2014, and the industry codes are used Harmonized System (HS) 50 to 63. The analytical method used is the Fixed Effects Model (FEM) using Least Square Dummy Variable (LSDV).

The results showed that the exchange rate, domestic production index are positive and have significant impact on the volume of Indonesian textile exports to ASEAN countries (Malaysia, Thailand, Vietnam, the Philippines and Cambodia). While international prices have positive effect and it not significant.
\end{abstract}

Keywords: $\quad$ TPT, ASEAN, International trade, FEM-LSDV, exchange rate JEL Classification: F-140

\section{PENDAHULUAN}

Sektor industri merupakan salah satu sektor yang berperan penting dalam pembangunan Indonesia. Hal ini dapat tercermin dari kontribusinya terhadap Produk Domestik Bruto (PDB) Indonesia yang cukup besar dibandingkan sektor lainnya yaitu sektor jasa dan sektor pertanian.

Menurut Todaro (1981) perdagangan internasional merupakan salah satu kunci dari pertumbuhan ekonomi suatu negara disamping konsumsi, investasi dan pengeluaran pemerintah. Di Indonesia ekspor terbagi menjadi dua golongan yaitu ekspor migas dan non migas. Jika melihat komposisi ekspor industri pengolahan yang terdiri dari industri migas dan industri non migas Indonesia mengalami perubahan dimana pada tahun 1980an Indonesia menitik beratkan ekspor pada industri migas, akan tetapi pada tahun 1987 ekspor Indonesia mulai didominasi oleh industri non migas. Perubahan ini dikarenakan adanya kebijakan pemerintah dan deregulasi di bidang ekspor.

Selama periode tahun 1984-2012 perkembangan nilai ekspor non migas Indonesia mengalami fluktuasi dimana rata-rata pertumbuhanya sebesar 12,2 persen setiap tahunnya. Perubahan ekspor migas Indonesia mulai menunjukkan penurunan drastis pada tahun 1985 ke 1986 yaitu dari 12717,8juta US\$ ke 8276,6 juta US\$ atau berubah -34,92 persen (Badan Pusat Statistik, 2014)

Industri Tekstil dan Produk Tekstil (TPT) mempunyai kontribusi terbesar kedua dalam nilai ekspor non migas Indonesia setelah komoditas minyak sawit. Nilai ekspor TPT Indonesia sendiri ratarata sebesar 12.481.550 juta US\$. Sedangkan nilai ekspor minyak sawit rata-rata sebesar 16.230.208 
juta US\$. Sementara itu rata-rata perubahan nilaiekspor TPT Indonesia selama tahun 2010-2013 sebesar 3,5 persen Seperti yang ditunjukkan pada tabel 1.

Tabel 1 Perkembangan Nilai Ekspor Non-Migas Indonesia Tahun 2010-2013 (juta US\$)

\begin{tabular}{|c|c|c|c|c|c|}
\hline \multicolumn{2}{|c|}{ Komoditas } & 2010 & 2011 & 2012 & 2013 \\
\hline \multicolumn{2}{|c|}{$\begin{array}{l}\text { Tekstil dan produk } \\
\text { tekstil }\end{array}$} & 11.292 .188 & 13.352 .823 & 12.510 .222 & 12.770 .966 .09 \\
\hline $\begin{array}{l}\text { Produk } \\
\text { olahan }\end{array}$ & kayu & 2.820 .894 & 3.246 .114 & 3.338 .150 & 3.510 .391 .69 \\
\hline Minyak sau & & 13.422 .626 & 17.294 .554 & 17.685 .128 & 16.518 .525 .47 \\
\hline Bahan kimi & & 3.425 .997 & 4.655 .547 & 3.634 .537 & 3.498 .624 .50 \\
\hline $\begin{array}{l}\text { Produk } \\
\text { dasar }\end{array}$ & logam & 9.876 .620 & 11.853 .787 & 9.303 .974 & 8.614 .178 .60 \\
\hline $\begin{array}{l}\text { Peralatan } \\
\text { dan optik }\end{array}$ & listrik & 10.947 .800 & 11.546 .386 & 11.157 .423 & 10.716 .148 .37 \\
\hline Semen & & 109.098 & 57.801 & 20.049 & 49.657.21 \\
\hline $\begin{array}{l}\text { Kertas dan } \\
\text { dari kertas }\end{array}$ & barang & $4.133,882$ & 4.154 .687 & 3.938 .383 & 3.732 .138 .33 \\
\hline Karet olaha & & $9.239,750$ & 14.128.206 & 10.368 .181 & 9.306 .376 .20 \\
\hline
\end{tabular}

Sumber : Bank Indonesia 2014

Besarnya kontribusi ekspor TPT terhadap ekspor total non migas Indonesia mengindikasikan betapa pentingnya sektor ini terhadap perekonomian Indonesia. Sebagai salah satu sektor dari industri non migas, Industri TPT dapat menjadi andalan dalam perdagangan Indonesia. Selain besarnya kontribusi terhadap total ekspor non migas Indonesia, Industri TPT juga mempunyai peranan penting dalam menopang pertumbuhan ekonomi. Hal ini bisa dilihat dari kontribusinya terhadap penyerapan tenaga kerja yang besar. Pada tahun 2013 penyerapan tenaga kerja industri TPT cukup besar jika dibandingkan dengan sektor lainnya yaitu mencapai 900.677 jiwa diikuti oleh sektor makanan dan minuman yaitu sebesar 877.424 jiwa (BPS, 2014).

TPT merupakan salah satu sektor yang mendapat prioritas pengembangan sektor prioritas Intra-ASEAN. Sektor ini dianggap penting karena dapat untuk pemenuhan kebutuhan sandang khususnya negara-negara ASEAN. Sektor industri TPT juga mempunyai prospek pasar yang menjanjikan dipasar ASEAN dengan melihat luas wilayah dan populasi ASEAN yang cukup besar dimana pada tahun 2013 populasi ASEAN mencapai 625.090,5 juta jiwa dan total wilayah mencapai4.435.618 $\mathrm{km}^{2}$ mampu menjadikan pasar tersendiri ditambah dengan pendapatan rata-rata perkapita mencapai US\$ 9.389,8 (ASEAN secretariat 2014).

Industri TPT dapat dikatakan sebagai industri yang terkena dampak dari adanya liberalisasi perdagangan hal itu dikarenakan adanya kebijakan penghapusan kouta impor tekstil pada tahun 2005 . Selain penghapusan kouta bentuk liberalisasi lainya adalah penghapusan kebijakan tarif dan non tarif khususnya diantara negara ASEAN sebagai akibat pemberlakuan Masyarakat Ekonomi ASEAN (MEA).

Tabel 2 menunjukkan dinamika nilai ekspor TPT Indonesia ke negara-negara ASEAN. Selama periode 2010-2013 ekspor TPT Indonesia ke negara-negara ASEAN mengalami pertumbuhan yang melambat pada tahun 2010 sampai 2012 total ekspor TPT Indonesia mengalami kenaikan namun pada tahun 2013 mengalami penurunan sebesar US\$ 20.209.340 secara parsial masing-masing negara hanya ekspor ke Myanmar dan ke Philipina yang selalu mengalami kenaikan pada tahun 2013. Penurunan ekspor TPT pada tahun 2013 ini juga dikuti dengan menurunnya ekspor nonmigas Indonesia di pasar internasional. 
Tabel 2 Perkembangan Nilai Ekspor Industri TPT Indonesia ke Negara ASEAN Tahun 2010-2013 (juta US\$)

\begin{tabular}{lrrrr}
\hline Negara & $\mathbf{2 0 1 0}$ & $\mathbf{2 0 1 1}$ & $\mathbf{2 0 1 2}$ & $\mathbf{2 0 1 3}$ \\
\hline Malaysia & 118.658 .137 & 132.034 .091 & 142.438 .594 & 139.212 .574 \\
Singapura & 59.554 .402 & 75.339 .261 & 85.117 .133 & 76.479 .508 \\
Thailand & 41.201 .430 & 33.316 .379 & 51.941 .269 & 51.914 .116 \\
Laos & 3.516 .712 & 3.612 .795 & 1.897 .192 & 1.714 .534 \\
Philipina & 25.270 .959 & 30.661 .634 & 31.708 .701 & 33.001 .533 \\
Vietnam & 27.480 .644 & 30.704 .245 & 43.709 .976 & 42.554 .748 \\
Brunei D & 2.366 .349 & 2.098 .090 & 2.491 .743 & 2.060 .140 \\
Kamboja & 3.005 .830 & 8.016 .031 & 19.980 .646 & 11.451 .649 \\
Myanmar & 2.296 .303 & 2.763 .403 & 2.452 .472 & 3.139 .584 \\
Total & 283.350 .766 & 318.545 .929 & 381.737 .726 & 361.528 .386 \\
\hline
\end{tabular}

Sumber : Un-comtrade diolah, 2014

Pangsa pasar ekspor TPT Indonesia ke ASEAN masih cukup kecil. Selama tahun 2010 sampai 2014 rata-rata hanya 6,5 persen dari total ekspor dunia. Pertumbuhan ekspor ke ASEAN pun juga relatif lamban. Kajian yang dilakukan Badan koordinasi penanaman modal (BKPM) menyebutkan pasar ASEAN hanya memberikan kontribusi sebesar 6 persen terhadap total pendapatan ekspor (tabel 3). Meskipun telah berlaku pasar bersama AFTA (ASEAN Free Trade Area), namun pangsa ekspor TPT ke ASEAN justru melemah dalam 10 tahun terakhir. Di tahun 2002 pasar ini mampu menyerap 8 persen ekspor TPT Indonesia, namun di tahun 2010 turun menjadi 6 persen. Produk-produk TPT yang mengandalkan pasar ASEAN antara lain Knitted or crocheted fabric (38\%), Wadding, felt, nonwovens, yarns, twine, cordage, etc (29\%), dan Special woven or tufted fabric, lace, tapestry etc (23\%) dan Manmade filaments (17\%).

Tabel 3 Pangsa Pasar Ekspor TPT Total Indonesia ke ASEAN Tahun 2010-2014 (juta (US\$)

\begin{tabular}{cccc}
\hline Tahun & Dunia (US\$) & ASEAN (U\$\$) & Pangsa pasar ASEAN (\%) \\
\hline 2010 & 11.224 .038 .003 & 694.155 .702 & 6,18 \\
2011 & 13.256 .791 .758 & 818.686 .042 & 6,18 \\
2012 & 12.468 .384 .228 & 831.882 .937 & 6,67 \\
2013 & 12.683 .713 .514 & 840.613 .321 & 6,63 \\
2014 & 12.742 .635 .101 & 879.598 .652 & 6,90 \\
\hline
\end{tabular}

Sumber : Badan Pusat Statistik diolah, 2015

Penurunan kinerja ekspor TPT Indonesia ke beberapa negara ASEAN disebabkan oleh beberapa hal diantaranya, keadaan perekonomian negara-negara ASEAN tidak stabil dan banyaknya produsen TPT dari negara ASEAN lainnya selain Indonesia. Pasar ASEAN dapat dijadikan sebagai pengganti pasar tradisional ke Amerika Serikat, Uni Eropa dan Jepang. Penyebab lainnya adalah masalah yang mengangkut infrastruktur dan efisiensi. Menurut laporan World Economic Forum 2014 diketahui adanya lima masalah utama dalam menjalankan bisnis di Indonesia yaitu infrastruktur yang buruk, ketidakefisienan birokrasi, keterbatasan akses pendanaan, kebijakan tidak stabil/inkonsisten kebijakan dan peraturan tenaga kerja yang restriktif. Dalam memulai bisnis di Indonesia mebutuhkan 48 hari, sedangkan di Singapura hanya memakan waktu 2,5 hari.

Secara umum menurut Nizar (2014) tingkat daya saing TPT Indonesia masih tergolong tinggi di negara ASEAN di mana rata-rata RCA $>1$, namun nilai daya saing Indonesia masih kalah jauh dari 
beberapa negara ASEAN lainya. Negara-negara di ASEAN dengan daya saing tertinggi di masingmasing produk masih didominasi oleh negara Thailand, Kamboja dan Vietnam sementara Indonesia memiliki nilai tertinggi hanya pada dua produk yaitu serat buatan lainnya untuk pemintalan dan kain,tenun,kain buatan manusia.

Industri TPT Indonesia masih mengalami beberapa permasalahan yang sangatlah kompleks yaitu, iklim usaha dan pasar dalam negeri. Perubahan iklim usaha memaksa terjadinya peningkatan biaya produksi. Adapun yang dimaksud dalam iklim usaha tersebut adalah kenaikan Bahan Bakar Minyak (BBM) dan Tarif Dasar Listrik (TDL). Kenaikan ini akibat krisis energi yang dihadapioleh beberapa negara. Selain itu, regulasi dan peraturan pemerintah yang tidak mendukung industri TPT juga memicu meningkatnya biaya produksi(Asosiasi PertekstilanIndonesia dalam BKPM 2012).

Faktor mesin menjadi salah satu isu utama dalam industri TPT di Indonesia. Penggunaan mesin yang sudah lama, sehingga mengalami penurunan produktivitas. Sementara itu, kekurangan dari industri TPT Indonesia adalah kurangnya ketersediaan mesin yang baik untuk melakukan produksi. Selama ini komponen hingga mesin jadi masih mengandalkan impor dari negara lain. Hal tersebut akan melemahkan daya saing industri TPT Indonesia (Media Industri,2013).

Naik turunnya volume ekspor suatu komoditas dapat dipengaruhi dari sisi penawaran ekspor menurut Lipsey (1995) faktor-faktor yang mempengaruhi penawaran ekspor komoditas diantaranya harga barang itu sendiri, tingkat faktor produksi, tingkat teknologi, nilai tukar.Literatur lain menyebutkan faktor-faktor yang mempengaruhi ekspor suatu negara diantaranya preferensi masingmasing negara, harga barang, nilai tukar, biaya produksi dan kebijakan pemerintah terkait perdagangan internasional (Mankiw, 2009).

Secara teori harga suatu komoditi mempunyai hubungan yang positif terhadap jumlah barang yang ditawarkan. Beberapa penelitian empiris membuktikan bahwa hubungan antara harga dengan barang yang ditawarkan adalah positif. Dalam penelitian Mustika (2009) harga internasional berpengaruh positif terhadap volume penawaran ekspor televisi ke Malaysia,Thailand dan Singapura. Penelitian lain juga menyebutkan bahwa harga internasional, produksi domestik, dan nilai tukar berhubungan positif dan signifikan dengan barang yang ditawarkan (Widyastuti, 2011).Pracoyo mengadopsi model permintaan dan penawaran ekspor yang telah dilakukan olehMuscatelli, Srinivasan, dan Vines (1992). Hasil adaptasinya bahwa penawaran ekspor tekstillndonesia dipengaruhi oleh harga tekstil, biaya bahan baku, upah, tarif, dan teknologi.Sedangkan dari sisi permintaan ekspor tekstil dipengaruhi oleh harga tekstil, harga tekstil dunia,harga barang substitusi (harga wool dunia), pendapatan negara lain, dan selera konsumen. Tujuan yang ingin dicapai dalam penelitian ini adalah mengetahui pengaruh indeks produksi TPT Indonesia, nilai tukar, dan harga internasional TPT dunia terhadap volume penawaran ekspor tekstil dan produk tekstil Indonesia ke Malaysia, Thailand, Vietnam, Philipina dan Kamboja dengan mengakomodasi perbedaan intersep yang ada.

\section{TINJAUAN PUSTAKA}

Salah satu faktor yang menyebabkan terjadinya perdagangan internasional adalah adanya perbedaan permintaan dan penawaran perbedaan ini terjadi karena tidak semua negara mampu menghasilkan komoditas yang diperdagangkan dan faktor produksi yang berbeda (Salvatore,1997). Menurut Lindert (1983) Dalam kurva permintaan dan penawaran memperlihatkan efek perdagangan internasional terhadap produksi, konsumsi dan harga. Beberapa faktor yang mempengaruhi penawaran suatu komoditi adalahharga komoditi yang bersangkutan, harga faktor produksi, tingkat teknologi, pajakdan subsidi (Lipsey et al., 1995). Kajian dari Tambunan, Abdurahman,Zuladin, Narjoko menjelaskan faktor yang mempengaruhi ekspor adalah kapasitas industri, harga dipasar internasional dan nilai tukar. (dikutip oleh Mukhyi, 2011).

Nilai tukar merupakan faktor yang mempengaruhi penawaran ekspor. Ketika nilai tukar mengalami depresiasi maka harga-harga barang luar negeri menjadi cenderung lebih murah dibandingkan dengan harga barang dalam negeri. begitupun sebaliknya. Dengan kata lain depresiasi nilai tukar cenderung akan meningkatkan ekspor karena secara teori hubungan antara nilai tukar dengan penawaran ekspor adalah positif.

Teori dasar penawaran menyatakan bahwa harga suatu komoditas mempunyai hubungan positif terhadap jumlah yang ditawarkan. Dalam perdagangan internasional harga yang dipakai adalah 
harga internasional. Hal ini berarti semakin tinggi harga internasional maka semakin besar pula jumlah yang ditawarkan.

Indeks produksi atau kapasitas produksi merupakan salah satu faktor yang mempengaruhi penawaran ekspor. Dengan bertambahnya produksi suatu barang maka akan meningkatkan penawaran suatu barang untuk diekspor.

\section{METODE PENELITIAN}

\section{Variabel Penelitian dan Definisi Operasional}

Penelitian ini menggunakan empat variabel, yaitu variabel terikat (dependent variable) berupa volume ekspor Tekstil dan Produk Tekstil (TPT) Indonesia ke negara ASEAN (Vietnam,Thailand, Malaysia, Philipina dan Kamboja) dan tiga variabel bebas (independent variable) yang terdiri dari harga internasional TPT, Indeks Produksi TPT domestik Indonesia dan Nilai Tukarrupiah terhadap dollar. Data yang dipakai adalah data bulanan dari bulan Januari 2011 sampai bulan Desember 2014. Sumber data berasal dari Badan Pusat Statistik (BPS), Un-comtrade, Kementerian Perdagangan dan Bank Indonesia. Definisi operasional variabel dari masing-masing variabel yang dipakai adalah sebagai berikut :

1. Volume ekspor TPT Indonesia ke beberapa negara ASEAN (Vietnam, Thailand, Malaysia, Philipina dan Kamboja) yaitu volume penjualan TPT Indonesia Ke Vietnam, Thailand, Malaysia, Philipina dan Kamboja dalam kurun waktu bulanan dari bulan Januari 2011 sampai Desember 2014 yang dihitung dalam satuan kg. Dimana dalam penelitian ini terdiri dari Harmonized System (HS) 50 sampai 63.

2. Harga internasional TPT adalah harga yang diperoleh dari hasil pembagian antara nilai ekspor TPT Indonesia total ke dunia dengan volume total ekspornya, dihitung dengan satuan (US\$/kg) dengan periode waktu bulan Januari 2011 sampai Desember 2014

3. Nilai tukaradalah nilai tukar valuta asing yang digunakan dalam pembayaran transaksi dalam perdagangan internasional. Nilai tukar yang dipakai adalah nilai tukar nominal. Periode waktu bulanan yaitu mulai Januari tahun 2011 sampai Desember 2014.

4. Indeks Produksi TPT Indonesia adalah keseluruhan untuk komoditi pakaian jadi, kain dan benang Indonesia yang diproduksi setiap bulanya dan dinyatakan dalam indeks (tahun dasar 2010=100) selama periode bulan Januari tahun 2011 sampai Desember 2014.

\section{Metode Analisis}

Dalam penelitian ini, model penawaran ekspor TPT Indonesia ke Vietnam, Thailand, Malaysia, Philipina dan Kambojabulan Januari 2011 sampai Desember 2014 digunakan asumsi Fixed Effect Model (FEM), yaitu koefisien slope konstan tetapi intersep bervariasi antar negara. Dalam hal ini, intersep dari masing-masing negara diasumsikan memiliki perbedaan yang disebabkan oleh karakteristik khusus yang dimiliki oleh masing-masing negara. Bentuk model Fixed Effect adalah dengan memasukkan variabel dummy untuk menyatakan perbedaan intersep. Ketika variabel dummy digunakan untuk mengestimasi fixed effect, maka persamaan tersebut disebut sebagai Least Square Dummy Variabel (LSDV). Penelitian ini menggunakan dummy negara, untuk melihat perbedaan perkembangan volume penawaran ekspor ke masing- masing neg Pada model penawaran ekspor TPT Indonesianegara Malaysia sebagai wilayah acuan (benchmark). Alasan penggunaan Malaysia sebagai benchmark pada model ini adalah Malaysia pengimpor terbesar TPT dari Indonesia. Dalam estimasi penelitian ini menggunakan standart error HAC (Heteroscedasticity and Autocorrelation-Consistent) atau Newey-West standart errorHAC (Heteroscedasticity and Autocorrelation Consistent) atau cukup dikenal dengan metode Newey-West merupakan metode yang digunakan untuk menyelesaikan permasalahan heteroskedastisitas dan autokorelasi, dimana metode ini melakukan koreksi terhadap standar error uktuk autokorelasi yang dikembangkan oleh Newey dan West (Gujarati, 2004). Metode ini merupakan perluasan dari heteroskedastisitas konsisten White. Adapun modelnya sebagai berikut :

$$
\mathrm{LnVol}_{\mathrm{ijt}}=\alpha_{\mathrm{i}}+\beta_{1} \mathrm{LnER}_{\mathrm{it}}+\beta_{2} \mathrm{LnHI}_{\mathrm{it}}+\beta_{3} \mathrm{IPD}_{\mathrm{it}}+\gamma 1 \mathrm{D}_{1}+\gamma 2 \mathrm{D}_{2}+\gamma 3 \mathrm{D}_{3}+\gamma 4 \mathrm{D}_{4}+\mu_{i t}
$$

dimana :

ai $\quad=$ Konstanta

$\beta \quad=$ Koefisien regresi 
LNVol = Logaritma natural volume ekspor TPT Indonesia ke negara $\mathrm{j}$ bulan ke- $\mathrm{t}(\mathrm{kg})$.

LNHI = Logaritma natural harga internasioanl bulan $\mathrm{ke}-\mathrm{t}(\mathrm{US} \$ / \mathrm{kg})$.

IPD = Indeks produksi domestik TPT Indonesia bulan ke- $\mathrm{t}$

LNER = Logaritma natural nilai tukar bulan $\mathrm{t}$.

$\mathrm{D}_{1} \quad=$ Dummy Thailand

$\mathrm{D}_{2} \quad$ = Dummy Vietnam

$\mathrm{D}_{3} \quad=$ Dummy Philipina

$\mathrm{D}_{4} \quad=$ Dummy Kamboja

$\mu_{i t} \quad=$ error

\section{HASIL DAN PEMBAHASAN}

\section{Gambaran Umum Industri dan Ekspor Tekstil dan Produk Tekstil Indonesia}

Industri tekstil dan produk tekstil di Indonesia terbagi dalam tiga sektor industri yang terintegrasi dari hulu hingga hilir (Djafri, 2003), pertama sektor industri hulu (upstream) Sifat dari sektor industri ini adalah padat modal, berskala besar, dan jumlah tenaga kerjanya relatif sedikit, tetapi output per tenaga kerjanya besar. Kedua sektor industri menengah (midstream) adalah Sektor industri ini memiliki karakteristik atau sifat semi padat modal, teknologi menengah dan modern, serta jumlah tenaga kerjanya lebih besar dari sektor industri hulu. Ketiga sektor industri hilir Pada sektor inilah yang paling banyak menyerap tenaga kerja sehingga industrinya bersifat padat karya.

Struktur biaya di industri TPT Indonesia sendiri masih didominasi oleh biaya bahan baku. Lebih dari 50 persen struktur biaya di sektor pembuatan serat (fiber making), pemintalan (spinning), tenun(weaving) dan garmen disumbangkan oleh biaya bahan baku. Industri hulu TPT sepertifiber making, spinning dan weaving lebih sensitif terhadap perubahan harga energikarena kontribusi biaya energi di sektor ini cukup tinggi. Sedangkan industri garmenlebih sensitif terhadap upah karena biaya tenaga kerja mencapai 27,1 persen dari total biaya produksi (Asosiasi Pertekstilan Indonesia, 2013).

Jika dilihat distribusi ekspor TPT Indonesia ke ASEAN dari tahun 2009 sampai 2014 mengalami beberapa perubahan diantaranya pada tahun 2009 sampai 2012 HS 54 yang mendominasi komposisi ekspor TPT Indonesia ke ASEAN, namun mulai tahun 2013 dan 2014 HS 55 mulai meningkat yang sebelumnya 55.004.108 menjadi 61.361.605. Kemudian HS 63 mengalami penurunan setiap tahunnya hingga 7.094.18.

Gambar 2 Distribusi Volume Ekspor TPT Indonesia ke ASEAN 2009-2014

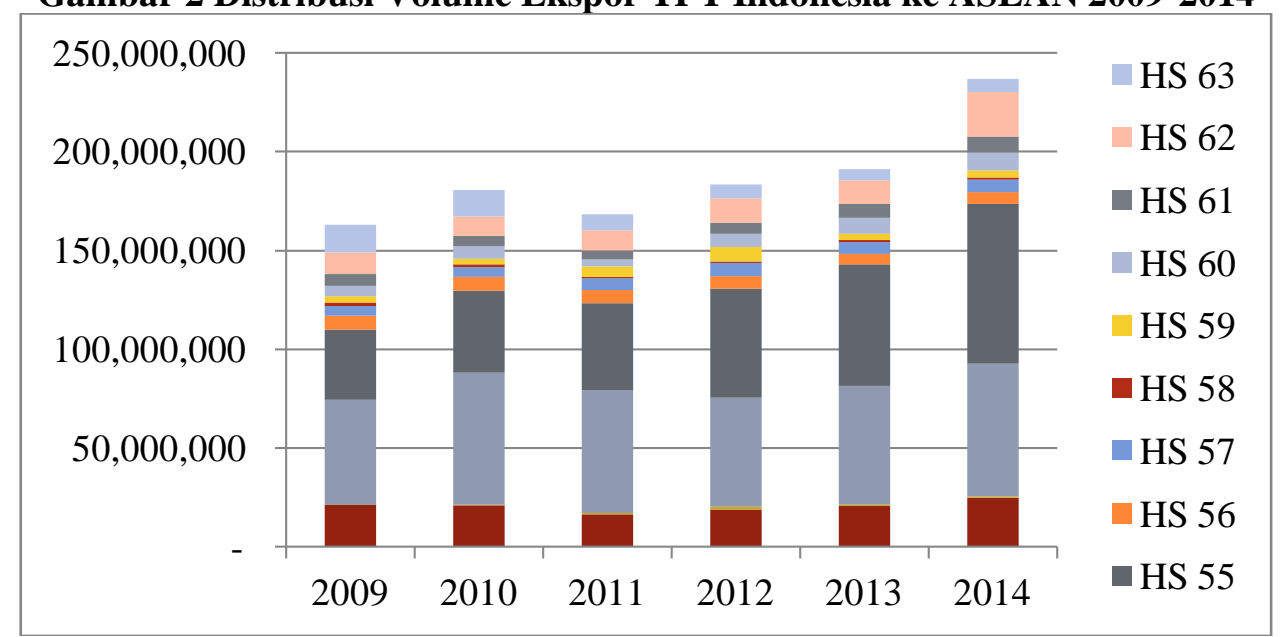

Sumber : Badan Pusat Statistik diolah, 2015

Berikut merupakan hasil estimasi model penawaran ekspor TPT Indonesia ke negara Malaysia, Thailand, Vietnam, Philipina dan Kamboja. Di mana sebelumnya melakukan estimasi dilakukan pengujian asumsi klasik diantaranya: normalitas, heteroskedastisitas, multikolinieritas dan autokorelasi. Untuk pengujian normalitas menggunakan uji Kolmogorov-Smirnov Z dengan nilai Asymtotic Signicance sebesar 0,251 maka dapat dikatakan normal. Uji heteroskedastisitas menggunakan uji white dengan nilai Chi Square 0,3801. Uji multikolinieritas menggunakan auxilliary 
regression di mana nilai $\mathrm{R}^{2}$ regresi utama lebih tinggi dari pada $\mathrm{R}^{2}$ secara parsial. Uji autokorelasi menggunakan uji DW. Dari hasil uji DW terdapat autokorelasi positif sehingga diperlukan perbaikan dengan metode HAC. Metode ini digunakan untuk mengkoreksi standar error sehingga secara otomatis menghilangkan autokorelasi (Gujarati, 2004).

Pada hasil regresi pengaruh nilai tukar (LnER), indeks produksi (IPD) dan harga internasional (LnHI)terhadap volume ekspor TPT Indonesia ke negara-negara ASEAN (Malaysia, Thailand, Vietnam, Philipina dan Kamboja) bulan Januari 2011 - Desember 2014 dengan menggunakan metode Least Squares Dummy Variable (LSDV). Diperoleh nilai koefisien regresi untuk setiap variabel dalam penelitian dengan persamaan sebagai berikut:

\section{LnVol $=6.272602+0.808819 *$ LnER $+0.053156 *$ LnHI $+0.014454 *$ IPD + Dummy variable $+\mu$}

Model regresi penawaran volume ekspor TPT mampu dioperasikan karena memenuhi asumsi klasik, yaitu BLUE (Best Linear Unbiased Estimate). Nilai koefisien regresi sangat tinggi $(0,95)$ menunjukkan kemampuan variasi variabel independen dalam menerangkan variasi variabel dependen. Secara statistik, variabel independen yaitu nilai tukar, indeks produksi dan bersama-mama memiliki pengaruh terhadap variabel dependen. Hasil dari pengujian hipotesis menunjukkan bahwa semua variable independen berpengaruh signifikan terhadap variabel dependen dengan menggunakan $\alpha=$ $5 \%$.

Tabel 4 Hasil Estimasi Model Penawaran Ekspor TPT Indonesia

\begin{tabular}{cc}
\hline Variabel & Coefficient \\
\hline C & 6,272602 \\
IPD & $(3,33)^{*}$ \\
& 0,014454 \\
LnER & $(2,15)^{* *}$ \\
& 0,808819 \\
LnHI & $(4,08)^{*}$ \\
& 0,053156 \\
D1 & $(0,37)$ \\
& 0,045615 \\
D2 & $(0,72)$ \\
& $-0,17094$ \\
D3 & $(-2,34)^{* *}$ \\
& $-1,19884$ \\
D4 & $(-18,09)^{*}$ \\
& $-3,10244$ \\
jumlah obs & $(-34,4)^{*}$ \\
R-Squared & 240 \\
F-Statistic & 0,958452 \\
\hline
\end{tabular}

Keterangan : angka dalam kurung merupakan nilai t statistik. Signifikan pada alfa $1 \% *$, alfa $5 \% * *$

Sumber : Data Sekunder diolah, 2015

Variabel harga internasional (LnHI)mempunyai koefisien yang positif terhadap volume ekspor TPT yang berarti semakin tinggi harga internasional semakin bertambah penawaran volume ekspor TPT Indonesia ke Malaysia, Thailand, Vietnam, Philipina dan Kamboja. Hal ini sesuai dengan hipotesis awal yang menduga bahwa harga internasional berpengaruh positif, Namun tidak signifikan hal ini dimungkinkan negara-negara di ASEAN lebih mementingkan kualitas produksi yang memiliki 
mutu terjamin dan baik sehingga harga tidak terlalu diperhatikan. Hasil ini sama dengan penelitian yang dilakukan oleh Maygirtasari (2015) dimana hasil penelitiannya menyebutkan bahwa harga internasional tidak berpengaruh signifikan terhadap volume ekspor CPO Indonesia.

Variabelnilai tukar (LnER)berpengaruh positif dan signifikan terhadap volume penawaran ekspor TPT Indonesia ke negara pengimpor (Malaysia, Thailand, Vietnam, Philipina dan Kamboja). Hal ini sesuai dengan teori awal yaitu pengaruh nilai tukar (LnER) terhadap volume penawaran TPT berpengaruh secara positif.Selain itu hasil ini juga sesuai dengan penelitian yang dilakukan oleh Mustika (2009), Firdaus (2007) dan Widyastuti (2011) bahwa nilai tukar berpengaruh positif dan signifikan. Saat nilai tukar rupiah terhadap dollar Amerika terdepresiasi maka hargabarang ekspor dalam negeri lebih mahal dari pada harga luar negeri, sehingga dayasaing meningkat dan keuntungan yang dapat diperoleh juga meningkat. Hal inimenyebabkan penawaran ekspor meningkat.

Variabel indeks produksi TPT domestik (IPD) berpengaruh secara signifikan terhadap volume penawaran ekspor TPT ke negara pengimpor (Malaysia, Thailand, Vietnam, Philipina dan Kamboja,). Hal ini sesuai dengan teori bahwa kenaikan produksi akan meningkatkan penawaran ekspor. Hasil ini juga sesuai dengan penelitian yang dilakukan oleh Firdaus (2007) dan Mustika (2009) yang dalam penelitiannya menyatakan bahwa produksi domestik berpengaruh positif dan signifikan terhadap volume ekspor Indonesia. Diharapkan semakin banyaknya industri TPT yang berkembang di Indonesia seiring dengan berkembangnya investasi pada industri TPT. Selain peningkatan jumlah industri TPT yang perlu diperhatikan adalah perbaikan mesin-mesin industri TPT yang sudah berumur tua.

Berdasarkan model fixed effect model dengan Dummy Variable mengasumsikan koefisien intersep bervariasi pada masing-masing negara, maka cara membaca variabel tersebut adalah dengan mengurangkan koefisien intersep regresi utama dengan nilai koefisien pada parameter dummy wilayah.

Tabel 5 Persamaan Regresi Setiap Negara

\begin{tabular}{|c|c|c|}
\hline No & Negara & Persamaan \\
\hline 1 & Malaysia & $\mathrm{LnVol}=6.27+0.808819 * \operatorname{LnER}+0.053156 * \mathrm{LnHI}+0.014454 * \mathrm{IPD}$ \\
\hline 2 & Thailand & $\mathrm{LnVol}=6.31+0.808819 * \operatorname{LnER}+0.053156 * \mathrm{LnHI}+0.014454 * \mathrm{IPD}$ \\
\hline 3 & Vietnam & $\mathrm{LnVol}=6.10+0.808819 * \operatorname{LnER}+0.053156 * \mathrm{LnHI}+0.014454 * \mathrm{IPD}$ \\
\hline 4 & Philipina & $\mathrm{LnVol}=5.07+0.808819 * \operatorname{LnER}+0.053156 * \mathrm{LnHI}+0.014454 * \mathrm{IPD}$ \\
\hline 5 & Kamboja & $\mathrm{LnVol}=3.17+0.808819 * \operatorname{LnER}+0.053156 * \mathrm{LnHI}+0.014454 * \mathrm{IPD}$ \\
\hline
\end{tabular}

Sumber : Data Sekunder Diolah, 2015

Dalam penelitian ini negara Malaysia dijadikan sebagai benchmark. Selanjutnya apabila hasil estimasi model fixed effect model dengan Dummy Variable diperoleh angka koefisien bernilai positif maka volume penawaran ekspor negara tersebut lebih tinggi dibanding Malaysia, sedangkan apabila angka koefisien bernilai negatif maka volume penawaran ekspor di negara tersebut lebih rendah dibanding Malaysia.

\section{KESIMPULAN}

Berdasarkan hasil yang diperoleh dari penelitian ini, secara keseluruhan semua variabel (uji F) yaitu harga internasional, indeks Produksi TPT, nilai tukar berpengaruhnya terhadap volume ekspor TPT Indonesia ke negara Malaysia, Thailand, Vietnam, Philipina dan Kamboja. Namun jika dilakukan pengujian setiap variabel (uji t) terdapat 2 variabel bebas yang berpengaruh secara signifikan terhadap volume penawaran ekspor TPT Indonesia ke Malaysia, Thailand, Vietnam, Philipina dan Kamboja yaitu indeks produksi TPT dan nilai tukar. Sedangkan untuk variabel harga internasional tidak berpengaruh secara signifikan terhadap volume ekspor TPT Indonesia ke negara Malaysia, Thailand, Vietnam, Philipina dan Kamboja.

\section{DAFTAR PUSTAKA}

ASEAN Secretariat, ASEAN Framework Agreement for the Integration of Priority Sectors, Vientiane, 29 November 2004. (http://www.aseansec.org/16659.htm) 
ASEAN secretariat. 2014. Asean Statistical Yearbook 2013. Jakarta.

Badan Koordinasi Penanaman Modal. 2012. Laporan Pengembangan Industri Tekstil dan Produk Tekstil 2011. BKPM. Jakarta.

Badan Pusat Statistik. 2013. Nilai Ekspor dan Impor . BPS. Jakarta.

Badan Pusat Statistik.2014. Industri Besar dan Sedang. BPS. Jakarta.

Bank Indonesia. 2014. Nilai Ekspor Non-Migas Indonesia. Bank Indonesia. Jakarta.

Djafri, Chamroel. 2003. Gagasan Seputar Pengembangan Industri dan Perdagangan TPT (tekstil dan produk tekstil). Jakarta.

Firdaus, Ahmad Heri. 2007. Analisis Daya Saing dan Faktor-Faktor Yang Mempengaruhi Ekspor Tekstil dan Produk Tekstil Indonesia di Pasar Amerika Serikat (Skripsi). Departemen Ilmu Ekonomi. Fakultas Ekonomi dan Manajemen. Institut Pertanian Bogor. Bogor.

Gujarati, Damodar N. 2004. Basic Econometrics. (4th ed). United States of American: Mc Graw-Hill Companies.

Http://comtrade.un.org/data

Http://www.aseansec.org

Junaidi, Mirwan. 2005. Analisis Faktor-Faktor Yang Mempengaruhi Penawaran Ekspor Teh Indonesia (Skripsi). Program Studi Ekonomi Pertanian dan Sumberdaya Fakultas Pertanian. Institut Pertanian Bogor. Bogor.

Kementrian Perindustrian. 2013. Mengukur Kesiapan Industri Nasional Jelang AEC 2015. Media Industri Edisi 2 halaman 7.

Lestari, Ayu. 2010. Analisis Faktor-Faktor Yang Mempengaruhi Penawaran Ekspor Karet Alam Indonesia (Skripsi). Program Studi Ekstensi Manajemen Agribisnis Fakultas Pertanian. Institut pertanian Bogor. Bogor.

Lindert, P.H and C.P. Kindleberger. 1983. International Economies. 7th edition.Terjemahan. Penerbit Erlangga. Jakarta.

Lipsey, R. G. 1995. Pengantar Mikroekonomi Jilid Kesatu. Binarupa Aksara: Jakarta.

Mankiw, N.Gregory. 2009. Principle of Economics: Pengantar Ekonomi Mikro (edisi ke-3). Jakarta: Salemba Empat.

Maygirtasari, Tyanma. Edy, Yulianto dan Mukhammad K.M. 2015. Faktor-Faktor Yang Mempengaruhi Volume Ekspor Crude Palm Oil (CPO) Indonesia. Jurnal Administrasi Bisnis (JAB). Vol. 25 No. 2 Agustus 2015.

Mukhyi, Abdul. Juarna, Asep. Ahmad B.M. 2011. Pengembangan Model Dinamika DanProyeksi Ekspor Indonesia Ke BeberapaNegara Mitra Dagang Utama. Usulan Penelitian. Universitas Gunadarma.

Mustika, Istiana. 2009. Analisis Daya Saing dan Faktor-Faktor Yang Mempengaruhi Penawaran Ekspor Televisi Indonesia ke Malaysia, Singapura dan Thailand (Skripsi). Departemen Ilmu Ekonomi, Fakultas Ekonomi dan Manajemen. Institut Pertanian Bogor. Bogor.

Nizar, Ardi. 2014. Dampak ASEAN Economic Community Terhadap Sektor Industri dan Jasa, Serta Tenaga Kerja di Indonesia. Badan kebijakan Fiskal. Jakarta.

Pracoyo, A. 1995. Pengaruh GATT Terhadap Perekonomian Indonesia, Studi Kasus Ekspor Industri Tekstil. Tesis Magister Manajemen. Program Pascasarjana, Universitas Gadjah Mada, Yogyakarta.

Salvatore, D. 1997. Ekonomi Internasional. Edisi Kelima, Jilid 1. Haris Munandar[Penerjemah]. Erlangga, Jakarta.

Tjokrosaputro, Michelle. 2013. Profile Of Indonesian Textile Industry. Asosiasi Pertekstilan Indonesia Jakarta.

Todaro, Michael P, (1981). Economic Development in The Third World, Second Edition, Published in The USA by Longman Inc.New York.

World Economic Forum. 2014. Laporan Daya Saing Global Tahun 2014-2015. Geneva.

Zaenal Ahmad dan Widyastuti.2011. Analisis Daya Saing dan Faktor Faktor Yang Mempengaruhi Ekspor CPO Indonesia ke China, Malaysia dan Singapura Dalam Skema ASEAN-China Free Trade Aggrement. Bogor : Jurnal Manajemen dan Agribisnis, Vol. 8 No 2 Oktober 2011. 